\title{
Bioconversion of hydrolyzed cashew peduncle bagasse for ethanol and xylitol production
}

\author{
Lorena L. de Medeiros ${ }^{1}$, Flávio L. H. da Silva², Sharline F. M. Santos², \\ Marta S. Madruga ${ }^{3}$, Débora J. N. de Melo² \& Líbia de S. Conrado ${ }^{4}$ \\ ${ }^{1}$ Universidade Federal da Paraíba/Centro de Tecnologia/Pós-Graduação em Ciência e Tecnologia de Alimentos. João Pessoa, PB. E-mail: lorenalucena@live.com \\ ${ }^{2}$ Universidade Federal da Paraíba/Centro de Tecnologia/Departamento de Engenharia Química. João Pessoa, PB. E-mail: flavioluizh@yahoo.com.br \\ (Corresponding author); sharlinefm@hotmail.com; deborajamila@gmail.com \\ ${ }^{3}$ Universidade Federal da Paraíba/Centro de Tecnologia/Departamento de Engenharia de Alimentos. João Pessoa, PB. E-mail: msmadruga@uol.com.br \\ ${ }^{4}$ Universidade Federal de Campina Grande/Centro de Ciências e Tecnologia/Unidade Acadêmica de Engenharia Química. Campina Grande, PB. E-mail: \\ libiac@deq.ufcg.edu.br
}

\section{Key words: \\ Anacardium occidentale L. \\ Candida guilliermondii \\ hemicellulose \\ bioproduction}

\begin{abstract}
A B S T R A C T
The agro-industrial waste deposited in the environment causes problems in nature that can be solved with the use and generation of bioproducts. Thus, the objective was to study the lignocellulosic fraction of cashew (Anacardium occidentale L.) peduncle bagasse and fermentation on large scale (8-16 times) using the strain Candida guilliermondii CCT-3544 as production agent. According to the obtained results, it can be noted that the dry cashew peduncle bagasse has $21.45 \%$ of cellulose, $10.96 \%$ of hemicellulose and $35.39 \%$ of lignin. During fermentation, C. guilliermondii 3544-CAT was able to grow on medium containing hydrolysate, with maximum cell growth concentration of $3.5 \mathrm{~g} \mathrm{~L}^{-1}$. The behavior of the sugars in the fermentation process was similar in the different variables, with maximum production of ethanol and xylitol at $48 \mathrm{~h}$ of fermentation.
\end{abstract}

Palavras-chave:

Anacardium occidentale L.

Candida guilliermondii

hemicelulose

bioprodução

\section{Bioconversão do hidrolisado do bagaço do pedúnculo do caju para produção de etanol e xilitol}

\begin{abstract}
R E S U M O
Os resíduos agroindustriais depositados no meio ambiente favorecem problemas na natureza, passíveis de serem solucionados com o aproveitamento e geração de bioprodutos. Assim, objetivou-se estudar a fração lignocelulósica do bagaço do pedúnculo do caju (Anacardium occidentale L.) e a fermentação em escala ampliada (8 a 16 vezes) utilizando a estirpe Candida guilliermondii CCT-3544 como agente de produção. De acordo com os resultados obtidos pode-se ressaltar que o bagaço do pedúnculo do caju seco possui $21,45 \%$ de celulose, $10,96 \%$ de hemicelulose e 35,39\% de lignina. Durante a fermentação, a C. guilliermondii CCT-3544 foi capaz de crescer no meio com hidrolisado sendo sua concentração máxima de crescimento celular $\left(3,5 \mathrm{~g} \mathrm{~L}^{-1}\right)$. O comportamento dos açúcares no processo fermentativo foi similar nas diferentes variáveis com produção máxima de etanol e xilitol em $48 \mathrm{~h}$ de fermentação.
\end{abstract}




\section{Introduction}

The Brazilian agricultural economy remains as one of the most important in the world, with performance superior to 186.1 million tons in the 2012/2013 season (Econ, 2013). Concomitantly with these levels, tons of agro-industrial wastes are generated, which are eliminated in the environment, producing excessive accumulation of organic matter in nature.

In this context, many of these wastes from the agro-industry can be used in biotechnological processes as raw material to obtain products with commercial value. Thus, various studies have demonstrated the potential of use of fermentable sugars, such as glucose and xylose, in the biosynthesis of products like ethanol and xylitol.

In Brazil, there are innumerous agro-industrial wastes favorable to the development of bioproducts, such as cashew (Anacardium occidentale L.), which is a tropical plant that has a pseudofruit with great potential for biotechnological development, since it is little used by the industry, with estimate of loss of more than $80 \%$ of the peduncle (Prommajak et al., 2014).

The utilization of cashew is recommended, due to its nutritional composition containing phenolic compounds, flavonoids, tannins, sugars like glucose and xylose and ascorbic acid (Sousa et al., 2016). Hence, the production of secondgeneration bioethanol has allowed the use of these biomasses in its production, which guarantees high selectivity of the product, low cost and safety (Chen et al., 2010).

Xylitol is a bioproduct that has attracted global attention for its sweetening power similar to that of sucrose, with low calories. In addition, it has anticariogenic property and is also considered by the Food and Drug Administration (FDA) as sugar substitute used in the food industry, being approved in more than forty countries (Mussato \& Roberto, 2002; Prakasham et al., 2009).

Given the large availability of cashew peduncle in the Northeast region, with more than $95 \%$ of the national production, and the need to employ a clean technology and minimize wastes from the industries, this research aimed to study the production of ethanol and xylitol using the liquor from the acid treatment of cashew peduncle bagasse as substrate, and the yeast Candida guilliermondii CCT-3544 as transformation agent.

\section{Material AND Methods}

The utilized raw material was cashew peduncle bagasse provided by the fruit pulp company IDEAL, João Pessoa, PB. Cashew peduncle bagasse was subjected to washings with distilled water at temperature of $50^{\circ} \mathrm{C}, 20 \mathrm{~min}$ each washing, to remove dirt and sugars that remain after pseudofruit pulp processing at proportion of 1:4, until reaching the content of total soluble solids equal to zero, expressed in ${ }^{\circ}$ Brix.

The bagasse was then taken on trays to convective dryers and subjected to temperature of $55^{\circ} \mathrm{C}$ for about $2 \mathrm{~h}$. The dry biomass was fragmented in knife mill to reduce fiber size to 48 mesh.

The liquor 1 used in the fermentation was obtained using a stainless-steel reactor with thermal controller (automation system for time and internal/external temperature) and maximum capacity of $0.7 \mathrm{~L}$. This reactor was loaded with $50 \mathrm{~g}$ of cashew peduncle bagasse for every $0.6 \mathrm{~L}$ of $3 \%$ sulfuric acid solution, a proportion that was defined based on previous studies. The hydrolysis time of $1 \mathrm{~h}$ in the reactor was recorded from the moment at which the temperature established in the experimental planning to obtain the fermentable sugars was achieved.

The liquor 2 was obtained from the dry cashew peduncle bagasse subjected to hydrolysis using 3\% sulfuric acid solution for $1 \mathrm{~h}$ to remove the hemicellulose fraction in a rotary reactor with nominal capacity of $20 \mathrm{~L}$. For that, $1.250 \mathrm{~kg}$ of bagasse were mixed with $15 \mathrm{~L}$ of $3 \%$ sulfuric acid solution. After that, the reactor was closed and the time started to be recorded when the process reached temperature of $160^{\circ} \mathrm{C}$ with pressure of $8 \mathrm{kgf} \mathrm{cm}^{-2}$ and the desired temperature was achieved at $105 \mathrm{~min}$ ( $1 \mathrm{~h} 45 \mathrm{~min})$. Then, temperature was reduced to $90{ }^{\circ} \mathrm{C}$ and, immediately after, the liquor was unloaded, filtered and centrifuged to remove the remaining impurities, resulting in $10 \mathrm{~L}$ of hydrolysate.

Part of the hydrolysate was concentrated in a digital rotary evaporator connected to a vacuum pump attached to a water cooling system through the SL 152/10 Ultra Thermostatic Bath using, as experimental parameters, rotation of $0.60 \mathrm{rpm}$, temperature of $80 \pm 5^{\circ} \mathrm{C}$ and $250 \mathrm{~mL}$ in each step, with time of about $3 \mathrm{~h}$ from the beginning to the end of the concentration.

This step aimed to increase the proportion of sugars in the liquors, especially xylose. Concentration was performed through the reduction of 2.5 times in its initial volume.

The determinations of extractives and analyses of lignocellulosic materials (lignin, cellulose, hemicellulose and holocellulose) were performed according to the methodology described by Morais et al. (2010).

The contents of sugar in the hydrolyzed liquor (xylose, glucose and arabinose) and inhibitors of fermentation (acetic acid, 5-Hydroxymethylfurfural and furfural) were determined using a High-Frequency Liquid Chromatograph (Varian, Waters, California, USA), equipped with an isocratic solvent system, "Rheodyne" valve with $20-\mu \mathrm{L}$ sample loop; attached to a Agilent Hi-Plex H column $(7.7 \times 300 \mathrm{~mm}, 8 \mu)$, at a temperature of $65^{\circ} \mathrm{C}$, refractive index detector (Varian) and the processing Software Galaxie Chromatography Data System. The mobile phase was $0.009 \mathrm{~mol} \mathrm{~L}^{-1} \mathrm{H}_{2} \mathrm{SO}_{4}$, at a flow rate of $0.6 \mathrm{~mL} \mathrm{~min}^{-1}$, and the run lasted for $1 \mathrm{~h}$.

The yeast used in the experiment was Candida guilliermondii CCT 3544, obtained in the Collection of Tropical Cultures (CCT) of the André Tosello Tropical Foundation of Research and Technology - FAT - Campinas, SP, which was maintained lyophilized at temperature of $28{ }^{\circ} \mathrm{C}$ until the moment of reactivation. Cells were reactivated by adding $0.2 \mathrm{~mL}$ of sterile distilled water, using a Pasteur pipette, in the vial with the lyophilized yeast, in sterile environment.

After $15 \mathrm{~min}$, all the content was transferred from the vial to a test tube containing $5.0 \mathrm{~mL}$ of the liquid culture medium yeast-malt extract $\left(3 \mathrm{~g} \mathrm{~L}^{-1}\right.$ of yeast extract, $3 \mathrm{~g} \mathrm{~L}^{-1}$ of malt extract, $5 \mathrm{~g} \mathrm{~L}^{-1}$ of peptone and $10 \mathrm{~g} \mathrm{~L}^{-1}$ of dextrose) and incubated at $28^{\circ} \mathrm{C}$ for 10 days.

The culture grown in the juice was subcultured to Petri dishes containing yeast-malt extract agar $\left(3 \mathrm{~g} \mathrm{~L}^{-1}\right.$ of yeast 
extract, $3 \mathrm{~g} \mathrm{~L}^{-1}$ of malt extract, $5 \mathrm{~g} \mathrm{~L}^{-1}$ of peptone and $20 \mathrm{~g}$ $\mathrm{L}^{-1}$ of agar) and incubated at $28{ }^{\circ} \mathrm{C}$ for $48 \mathrm{~h}$. Yeast growth was studied using cells of Candida guilliermondii CCT 3544, which were transferred under aseptic conditions from the Petri dishes to tubes containing $5 \mathrm{~mL}$ of sterilized distilled water. Subsequently, $2 \mathrm{~mL}$ aliquots of this suspension were transferred to erlenmeyer flasks containing $100 \mathrm{~mL}$ of the culture medium with $30 \mathrm{~g} \mathrm{~L}^{-1}$ of xylose, $2 \mathrm{~g} \mathrm{~L}^{-1}$ of ammonium sulfate, $0.1 \mathrm{~g} \mathrm{~L}^{-1}$ of calcium chloride and $20 \mathrm{~g} \mathrm{~L}^{-1}$ of rice bran extract (obtained from heating in autoclave at $111^{\circ} \mathrm{C}-0.5$ atm for $15 \mathrm{~min}$ with later centrifugation for $30 \mathrm{~min}$ under aseptic conditions at $2000 \mathrm{x}$ g, subsequently using only the supernatant as rice bran extract solution) employed in the study of Lima et al. (2014).

This culture medium was autoclaved and its $\mathrm{pH}$ was adjusted to 5.5. After inoculation, the flasks were incubated at $28{ }^{\circ} \mathrm{C}$ in shaker, with rotation of $200 \mathrm{rpm}$ for $24 \mathrm{~h}$. After this period, the cells were separated by centrifugation at 2000 $\mathrm{x} g$ for $30 \mathrm{~min}$ and re-suspended in sterilized distilled water, to obtain a solution with cell concentration of $50 \mathrm{~g} \mathrm{~L}^{-1}$. This suspension was used to calculate the volume necessary to provide the initial cell concentration of $3 \mathrm{~g} \mathrm{~L}^{-1}$.

Cell biomass was monitored, in duplicate, based on the measurement of optical density at $600 \mathrm{~nm}$ in spectrophotometer, whose cell concentration in $\mathrm{g} \mathrm{L}^{-1}$ was calculated using a calibration curve that correlates the absorbance and concentration in dry weight of the cells. Distilled water was used as control sample. The calibration curve was determined by reading the optical density of the suspensions, in duplicate, obtained through dilution of a cell suspension with known optical density and concentration in dry weight.

The concentration in dry weight of the initial cell suspension was determined gravimetrically. Cultured juice $(2 \mathrm{~mL})$ were centrifuged in previously dried and weighed tubes, in five replicates. After centrifugation, the supernatant was discarded and the cell biomass was dried in an oven at $105^{\circ} \mathrm{C}$, for $24 \mathrm{~h}$.

The cultures were conducted considering, as a reference, the best results obtained in the study of Lima et al. (2014), using the hydrolysate supplemented with $1 \mathrm{~g} \mathrm{~L}^{-1}$ of ammonium sulfate, $0.5 \mathrm{~g} \mathrm{~L}^{-1}$ of calcium chloride, $5 \mathrm{~g} \mathrm{~L}^{-1}$ of rice bran, $\mathrm{pH}$ 4.0 , with agitation of $200 \mathrm{rpm}$ at temperature of $28{ }^{\circ} \mathrm{C}$, for $120 \mathrm{~h}$. The medium with hydrolyzed liquor 1 was placed in $1 \mathrm{~L}$ erlenmeyer flasks, with $0.4 \mathrm{~L}$ of medium, being sterilized, cooled and inoculated with C. guilliermondii, provided that the initial concentration was $3 \mathrm{~g} \mathrm{~L}^{-1}$.

On the other hand, the test with Bioreactor (hydrolyzed liquor 2) used 1.6 L of liquor, pre-treated, concentrated and supplemented under the same culture conditions on stirring table, in duplicate. The experiments were carried out in TEC-
BIO bioreactor-fermenter, with capacity for $4.5 \mathrm{~L}$ and height of the reservoir with lid of $53 \mathrm{~cm}$.

The fermentation process was evaluated considering the parameters volumetric productivity $\left(\mathrm{Q}_{\mathrm{p}}\right)$, conversion factor $\left(\mathrm{Y}_{\mathrm{P} / \mathrm{S}}\right)$ efficiency $(\eta)$ with 0.40 and $1.6 \mathrm{~L}$. The parameters were calculated after $48 \mathrm{~h}$ of fermentation.

\section{Results AND Discussion}

According to the characterization of the lignocellulosic composition of the dry cashew peduncle bagasse (Table 1), it consisted of $21.45 \%$ of cellulose, $10.96 \%$ of hemicellulose, $35.39 \%$ of lignin and $9.51 \%$ of extractives.

Albuquerque et al. (2014) evaluated xylitol production from cashew peduncle bagasse using Kluyveromyces marxianus CCA510 and reported values of $17.73 \%$ of cellulose, $19.22 \%$ of hemicellulose, $33.41 \%$ of lignin and $6.41 \%$ of extractives, indicating a substantial amount of hemicellulose, compared with the results found in the present study.

Similar values were found by Rocha et al. (2009), who analyzed dried and hydrolyzed cashew peduncle bagasse and observed values of $19.21,12.0$ and $38.11 \%$ for cellulose, hemicellulose and lignin, respectively. In addition, Lima et al. (2012) also observed similar results for dry cashew peduncle bagasse (18.31\% cellulose; $27.18 \%$ hemicellulose and $23.91 \%$ lignin).

The values presented in the characterization, despite being close to those cited in the literature, differ due to the differences of season and cultivated species.

Table 2 shows the data of the hydrolyzed liquor of cashew peduncle bagasse. According to the results, xylose is the predominant sugar in the hydrolysate in the concentrated liquor, followed by glucose and arabinose originated during the acid hydrolysis of the lignocellulosic biomass. Regarding the amount of glucose in the hydrolysate, Lima et al. (2012) found similar amount $\left(1.78 \mathrm{~g} \mathrm{~L}^{-1}\right)$; however, the amounts of xylose and arabinose (1.43 and $7.12 \mathrm{~g} \mathrm{~L}^{-1}$, respectively) were different in the present study.

During the concentration process, the values of 5-hydroxymethylfurfural (HMF) and furfural were minimized due to the drag of these compounds along with the condensate.

Table 1. Lignocellulosic composition of the dry cashew peduncle bagasse

\begin{tabular}{lc}
\hline Composition & Dry cashew bagasse (\%) \\
\hline Extractives & $9.51 \pm 0.50$ \\
Cellulose & $21.45 \pm 0.31$ \\
Hemicellulose & $10.96 \pm 0.31$ \\
Holocellulose & $32.41 \pm 0.33$ \\
Lignin & $35.39 \pm 0.97$ \\
\hline
\end{tabular}

Table 2. Characteristics of hemicellulosic and concentrated hydrolysate of cashew peduncle bagasse

\begin{tabular}{lccc}
\hline \multicolumn{1}{c}{ Composition } & Hydrolyzed liquor 1 & Hydrolyzed liquor 2 & Concentrated hydrolyzed liquor \\
\cline { 2 - 4 } Glucose & & & Condensed \\
Xylose & 2.1756 & 2.5497 & 5.1972 \\
Arabinose & 5.4311 & 5.1706 & 10.5521 \\
Acetic acid & 3.8136 & 3.0317 & 6.0515 \\
5-hydroxymethylfurfural & 0.2039 & 0.0844 & 0.0000 \\
Furfural & 0.3947 & 0.1526 & 0.0005 \\
\hline
\end{tabular}


However, compounds toxic to the yeasts could be observed, such as acetic acid, $0.2039 \mathrm{~g} \mathrm{~L}^{-1}$ in the hydrolyzed liquor 2, $0.0844 \mathrm{~g} \mathrm{~L}^{-1}$ in the hydrolyzed liquor 1 and $0.0865 \mathrm{~g} \mathrm{~L}^{-1}$ in the concentrate; furfural $\left(0.4545 ; 0.2869\right.$ and $\left.0.1316 \mathrm{~g} \mathrm{~L}^{-1}\right)$ and hydroxymethylfurfural $\left(0.3947 ; 0.1526 ; 0.1154 \mathrm{~g} \mathrm{~L}^{-1}\right)$, which were generated from the degradations of pentoses and hexoses during the heating through chemical reactions originated in the acid hydrolysis.

Silva et al. (2007) reported that concentrations above $3 \mathrm{~g} \mathrm{~L}^{-1}$ of acetic acid, $1.5 \mathrm{~g} \mathrm{~L}^{-1}$ of hydroxymethylfurfural and $1 \mathrm{~g} \mathrm{~L}^{-1}$ of furfural have toxic effect enough to inhibit the action of microorganisms in the fermentation process.

In addition, the concentrations found by Lima et al. (2012) were $0.3437 \mathrm{~g} \mathrm{~L}^{-1}$ of acetic acid, which is similar to that found in the hydrolyzed liquor $2\left(0.2039 \mathrm{~g} \mathrm{~L}^{-1}\right)$; for furfural $\left(0.00002 \mathrm{~g} \mathrm{~L}^{-1}\right)$ and hydroxymethylfurfural $\left(0.00009 \mathrm{~g} \mathrm{~L}^{-1}\right)$, the results were different from those of the present study.

Regarding the biomass data presented in Figure 1, cell growth was observed in the hydrolyzed liquor 1 up to $12 \mathrm{~h}$ of fermentation ( 3 to $3.5 \mathrm{~g} \mathrm{~L}^{-1}$ ), maximum growth with decrease at $36 \mathrm{~h}\left(2 \mathrm{~g} \mathrm{~L}^{-1}\right)$, stabilizing until $120 \mathrm{~h}$ of operation. Bier et al. (2007) studied growth and xylose consumption using Candida guilliermondii in the hydrolyzed liquor of sugarcane bagasse and found maximum growth at $48 \mathrm{~h}$ of fermentation.

In the $1.6 \mathrm{~L}$ hydrolysate (Figure $1 \mathrm{~B}$ ), there was a reduction of cell concentration up to $12 \mathrm{~h}$, with growth from 12 to $36 \mathrm{~h}$ (2.5 $\left.\mathrm{g} \mathrm{L}^{-1}\right)$ for A2; nevertheless, for A1 the growth only started from $48 \mathrm{~h}$ of fermentation, reaching its maximum at $72 \mathrm{~h}(3.5$ $\left.\mathrm{g} \mathrm{L}^{-1}\right)$, after which there was a decrease in cell concentration.

According to Figure 2A, there was a variation in the concentrations of glucose, xylose, arabinose and xylitol production during the $120 \mathrm{~h}$ of fermentation. It is noticed that the sugars present in the fermented hydrolysate were consumed in the first $12 \mathrm{~h}$, with slight consumption between 12 and $48 \mathrm{~h}$, and remaining constant along the fermentation. The values confirmed by the xylitol production were $100 \%$ with $48 \mathrm{~h}$.

Zhang et al. (2012) studied xylitol production using Candida athensensis SB18 and observed total xylose consumption at

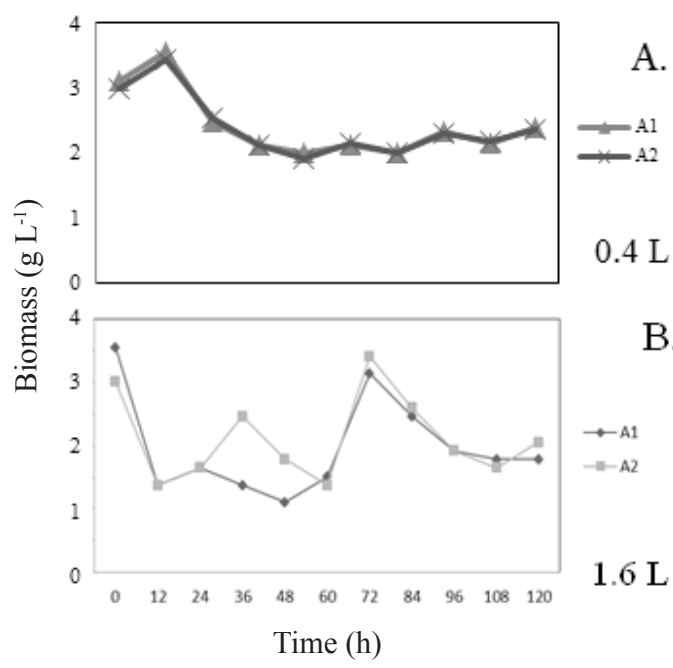

$A 1$ and $A 2$ are replicates

Figure 1. Variation of biomass concentration during the fermentation of the hemicellulosic hydrolysate of cashew peduncle bagasse with hydrolyzed liquor $1-0.40 \mathrm{~L}(\mathrm{~A})$ and hydrolyzed liquor 2 - 1.6 L (B)

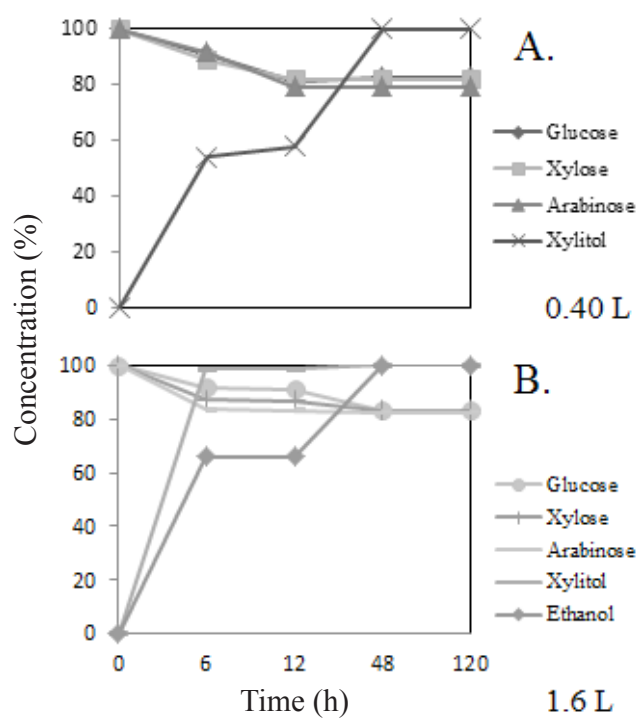

Figure 2. Variation in the concentration of glucose, xylose, arabinose, ethanol in the fermentation of the hydrolyzed liquor 1 (A) and hydrolyzed liquor 2 (B) of cashew peduncle bagasse

$288 \mathrm{~h}$ of fermentation and maximum xylitol concentration at $264 \mathrm{~h}$. The detoxified hemicellulosic hydrolyzed concentrate was supplemented with nitrogen source of the yeast extract; urea, $\mathrm{Na}_{2} \mathrm{HPO}_{4} ; \mathrm{KH}_{2} \mathrm{PO}_{4}$. The $\mathrm{pH}$ of the medium was adjusted to 7.0 and controlled with $2 \mathrm{M} \mathrm{NaOH}$ solution.

Figure $2 \mathrm{~B}$ shows that the sugars were consumed in the first $6 \mathrm{~h}$ and remained constant until $12 \mathrm{~h}$. Maximum consumption of sugars occurred at $48 \mathrm{~h}$, values that were confirmed by the xylitol concentration, equal to $98.6 \%$ in the first $6 \mathrm{~h}$, obtaining $100 \%$ with $48 \mathrm{~h}$ of fermentation. Ethanol was produced simultaneously to the obtainment of xylitol, with glucose consumption at $48 \mathrm{~h}$ of fermentation and maximum ethanol production in the first $48 \mathrm{~h}$, remaining constant until $120 \mathrm{~h}$.

Huang et al. (2011) studied the kinetic profile of Candida tropicalis JH030 during the fermentation of non-detoxified rice straw hydrolysate and reported the consumption of sugars (glucose, xylose and arabinose) at $80 \mathrm{~h}$ of fermentation, with simultaneous production of ethanol and xylitol, using $60 \mathrm{~mL}$ of hydrolysate with $\mathrm{pH}$ adjusted to 6.0 , temperature of $30{ }^{\circ} \mathrm{C}$ and rotation in shaker of 100-150 rpm. The pre-inoculum was prepared with $10 \mathrm{~g} \mathrm{~L}^{-1}$ of yeast extract, $20 \mathrm{~g} \mathrm{~L}^{-1}$ of peptone and $20 \mathrm{~g} \mathrm{~L}^{-1}$ of glucose.

Sene et al. (2000) report the preference for the consumption of glucose, compared with xylose, a trend found in this study for Candida guilliermondii CCT 3544.

\section{Conclusions}

1. The characterization of the lignocellulosic composition of dry cashew peduncle bagasse demonstrates the potential of this agro-industrial waste for xylitol production.

2. C. guilliermondii CCT-3544 obtained maximum cell growth concentration $\left(3.5 \mathrm{~g} \mathrm{~L}^{-1}\right)$ in the medium with concentrated hydrolysate $(0.40 \mathrm{~L})$ in the first $12 \mathrm{~h}$; for the hydrolysate fermented in the bioreactor $(1.6 \mathrm{~L})$, there was a variation in its cell concentration, reaching maximum of $3.5 \mathrm{~g} \mathrm{~L}^{-1}$ at $72 \mathrm{~h}$. 
3. The behavior of the sugars in the fermentation process was similar in the different variables $(0.40 \mathrm{~L}$ in shaker and 1.6 $\mathrm{L}$ in bioreactor).

\section{ACKnowledgments}

The authors thank the financial support from the National Council for Scientific and Technological Development (CNPq), and the André Tosello Foundation (FAT), which provided the yeast Candida guilliermondii CCT-3544, fundamental for this research.

\section{Literature Cited}

Albuquerque, T. L. de; Silva Júnior, I. J. da; Macedo, G. R. de; Rocha, M. V. P. Biotechnological production of xylitol from lignocellulosic wastes: A review. Process Biochemistry, v.49, p.1779-1789, 2014. https://doi.org/10.1016/j.procbio.2014.07.010

Bier, M. C. J.; Maranho, L. T.; Azevedo, J. A. M.; Silva Júnior, L. S. da. Crescimento e consumo de xilose de Candida guilliermondii na fermentação submersa utilizando-se bagaço de cana-de-açúcar. Evidência, v.7, p.119-130, 2007.

Chen, X.; Jiang, Z-H.; Chen, S.; Qin, W. Microbial and bioconversion production of $\mathrm{D}$-xylitol and its detection and application. International Journal of Biological Sciences, v.6, p.834-844, 2010. https://doi.org/10.7150/ijbs.6.834

Econ, L. BRASIL: Ministério da Agricultura, Pecuária e Abastecimento - MAPA Secretaria de Política Agrícola - SPA, 2013. 1-7p.

Huang, C. F.; Jiang, Y. F.; Guo, G. L.; Hwang, W. S. Development of a yeast strain for xylitol production without hydrolysate detoxification as part of the integration of co-product generation within the lignocellulosic ethanol process. Bioresource Technology, v.102, p.3322-3329, 2011. https://doi.org/10.1016/j. biortech.2010.10.111

Lima, F. C. dos S.; Silva, F. L. H. da; Gomes, J. P.; Muniz, M. B.; Santiago, A. M.; Silva, C. G. Biotechnological production of xylitol: Evaluation of detoxification process with residual lignin using response surface methodology. Chemical Engineering Transactions, v.38, p.415-420, 2014. https://doi.org/10.4236/ aces.2012.24064
Lima, F. C. dos S.; Silva, F. L. H. da; Gomes, J. P.; Silva Neto, J. M. da. Chemical composition of the cashew apple bagasse and potential use for ethanol production. Advances in Chemical Engineering and Science, v.2. p.519-523, 2012.

Morais, J. P. S.; Rosa, M. F.; Marconcini, J. M. Procedimentos para análises lignocelulósicas. Campina Grande: Embrapa Algodão, 2010. 21-42p.

Mussato, S. I.; Roberto, I. C. Xylitol: A sweetner with benefits for human health. Revista Brasileira de Ciências Farmacêuticas, v.38, p.401-413, 2002.

Prakasham, R. S.; Rao, R. S.; Hobbs, P. J. Current trends in biotechnological production of xylitol and future prospects. Current Trends in Biotechnology and Pharmacy, v.3, p.8-36, 2009.

Prommajak, T.; Leksawasdi, N.; Rattanapanone, N. Biotechnological valorization of cashew apple: A review. Chiang Mai Journal of Natural Sciences, v.13, p.159-182, 2014. https://doi.org/10.12982/ cmujns.2014.0029

Rocha, V. M. P.; Rodrigues, T. H. S.; Macedo, G. R. de; Gonçalves, L. R. B. Enzymatic hydrolysis and fermentation of pretreated cashew apple bagasse with alkali and diluted sulfuric acid for bioethanol production. Applied Biochemistry and Biotechnology, v.155, p.104-114, 2009. https://doi.org/10.1007/s12010-008-8432-8

Sene, L.; Vitolo, M.; Felipe, M. G. A.; Silva, S. S. Effect of environmental conditions on xylose reductase and xylitol dehydrogenase production in Candida guilliermondii. Applied Biochemistry and Biotechnology, v.84, p.371-80, 2000. https://doi.org/10.1385/ABAB:84-86:1-9:371

Silva, D. D. V. da; Mancilha, I. M. de; Silva, S. S. da; Felipe, M. das G. de A. Improvement of biotechnological xylitol production by glucose during cultive of Candida guilliermondii in sugarcane bagasse hydrolysate. Brazilian Archives of Biology and Technology, v.50, p.207-215, 2007. https://doi.org/10.1590/S151689132007000200005

Sousa, S. L.; Morais, B. A. de; Ribeiro, L. C.; Costa, J. M. C. da. Stability of cashew apple juice in powder dehydrated in spouted bed. Revista Brasileira de Engenharia Agrícola e Ambiental, v.20, p.678-682, 2016. https://doi.org/10.1590/1807-1929/agriambi. v20n7p678-682

Zhang, J.; Geng, A.; Yao, C.; Lu, Y.; Li, Q. Xylitol production from D-xylose and horticultural waste hemicellulosic hydrolysate by a new isolate of Candida athensensis SB18. Bioresource Technology, v.105, p.134-141, 2012. 